\title{
'Usefulness' in Contemporary Art and Politics
}

\section{Larne Abse Gogarty}

Recent discourse on socially engaged art, or social practice, has increasingly emphasised usefulness, as exemplified by Cuban artist Tania Bruguera's establishment of the 'Asociación de Arte Útil' in 2011, which has since developed partnerships with major art institutions such as the Queens Museum, the Van Abbemuseum and the Middlesbrough Institute of Modern Art (mima). Beyond the Asociación and Bruguera's practice, the notion of usefulness has permeated the field of social practice more broadly, with 'use value' frequently posed as an undisputed moral good, and a category that might be wrested from its socio-economic relation to exchange value within capitalism. Here, I analyse Arte Útil's affirmation of usefulness and 'use values' in relation to Marxist, post-Marxist and feminist theories of social reproduction, also drawing in issues of race and migration. The central question is this: how can we understand the aesthetic and political stakes of artworks that strive to be 'useful' through performing tasks associated with social reproduction as they have historically taken place in the home or via the welfare state?

I begin by plotting how I view the evolution of usefulness as prized characteristic in recent social practice through discussing exhibitions and the affiliation of institutions to the notion of Arte Útil, particularly focusing on mima. After outlining these developments, I address how 'usefulness' relates to the dialectic struck up between art and life within the avant-garde, stressing that 'life' needs to be thought alongside labour power and social reproduction as historically contingent categories. Next, I examine how the affirmation of 'use' relates to broader discussions on the left. In particular, I address recent philosophical-political strategies including 
accelerationism ${ }^{1}$, that like Arte Útil, frequently place too much stock in the forces rather than the relations of production within capitalism. ${ }^{2}$ As I will stress, 'forces of production' arguments that push technocratic solutions as the path towards social change are too frequently marked by an over-investment in the virtues of being realistic, rational and indeed useful. I write this at the tail end of 2016, where the supposedly improbable (at least in the white, liberal imagination) has happened on both sides of the Atlantic in the shape of Brexit and the election of Donald Trump. If there is anything this moment should tell us, it is that the centre ground - the so-called realistic and the rational - has failed and seemingly has nothing to offer us, or our worst enemies. Rather than sink into nihilism or attempt to produce a left-populism that cynically seeks to capture this moment through promoting a nostalgic nationalism, we need a movement and art that is full of expressive feeling, material and emotional solidarity, and an unrelenting refusal to acquiesce or become useful to our enemies in any way.

\section{ARTE ÚTIL}

\footnotetext{
${ }^{1}$ For a critical history of accelerationism through the $20^{\text {th }}$ century, see Benjamin Noys, Malign Velocities: Accelerationism and Capitalism, Zero Books, Winchester, 2014

${ }^{2}$ One useful example in understanding this distinction comes from Charles Tolman who suggests that alienation will only be countered by transforming the relations of production, whereas environmental damage could be addressed through the forces of production. Yet, as Tolman stresses, 'Environmental problems... will remain unsolved not because capitalism is incapable of developing the necessary forces of production, but because its priorities, its relations, will necessarily stifle such developments.' (Emphasis added) See C. Tolman, 'Karl Marx, Alienation, and the Mastery of Nature', in Bob Jessop and Russell Wheatley, eds, Karl Marx's Social and Political Thought, London and New York, 1999, p 25
} 
Bruguera's establishment of the Asociación de Arte Útil in 2011 follows on from her earlier practice which she had categorised under the title 'Arte de Conducta' (usually translated as 'Behaviour Art'), a term that sought to distance performance from spectacle and instead to foreground the social. ${ }^{3}$ One of the most notable instances of Arte de Conducta was Bruguera's establishment of the Cátedra Arte de Conducta (Behavior Art Department). Conceived in 1998, and executed between 2002-2009, this project was essentially a school for Arte de Conducta, forming a key gestation point for the later development of 'Arte Útil' (Useful Art) as an association which artists and institutions can declare affinities with. Such affinities are guided by an eight-point programme that projects must meet if they are to be deemed useful, with this also informing the curatorial strategy of exhibitions such as the 'Museum of Arte Útil', held at the Van Abbemuseum in Eindhoven (2013-2014). The eight criteria for Arte Útil are as follows:

To be useful, projects must:

1. Propose new uses for art within society

2. Challenge the field within which it operates (civic, legislative, pedagogical, scientific, economic, etc.)

3. Be 'timing specific', responding to current urgencies.

4. Be implemented and function in real situations.

5. Replace authors with initiators and spectators with users.

6. Have practical, beneficial outcomes for its users.

7. Pursue sustainability while adapting to changing conditions.

\footnotetext{
${ }^{3}$ Francesca di Nardo, 'Arte de Conducta', Janus, vol.I, no. 22., January 2007, p 81
} 
8. Re-establish aesthetics as a system of transformation. ${ }^{4}$

Bruguera's Immigrant Movement International (IMI) project is a key work within the development of Arte Útil and was included in the Van Abbemuseum exhibition. IMI is described as an 'artist-initiated socio-political movement' that focuses on the political representation and support of migrants; the project was funded by the Queens Museum and Creative Time, and initially based out of a community space in Corona, Queens. ${ }^{5}$ Also included in the Van Abbemuseum exhibition were projects by an international selection of artists and activists including WochenKlauser, Women on Waves, the 'Rolling Jubilee' movement and Theaster Gates. This work was grouped under various headings such as 'Reforming Capital', 'Legislative Change' and 'Space Hijack' that denoted the different political and aesthetic strategies on display within the exhibition.

The category of Arte Útil - and the notion of usefulness expressed in the eightpoint programme that guided the exhibition - serves to form a broad church of artists and artworks that cohere loosely around some broad principles that emphasise the importance of results that can be seen and perhaps even measured, as indicated by the notion of 'practical, beneficial outcomes'. Other aspects are more speculative, such as the desire to '(r)e-establish aesthetics as a system of transformation', meaning that Arte Útil as a genre tends to straddle the poles of utilitarianism and utopianism.

Alongside the Van Abbemuseum, Creative Time and the Queens Museum, mima presents one of the clearest institutional allegiances to Arte Útil, following its recent rebranding. Describing itself as a 'useful museum, a civic institution that promotes art

\footnotetext{
${ }^{4}$ See the Arte Útil website at http://www.arte-util.org/about/colophon/, accessed 18 July 2016 5 See Tania Burguera's website: http://www.taniabruguera.com/cms/486-0Immigrant+Movement+International.htmm, accessed 18 July 2016
} 
as a tool for social change ${ }^{, 6}$, mima's affiliation with Arte Útil was prompted by the move of Alastair Hudson into the role of Director in October 2014; Hudson also happens to be the co-director, along with Bruguera, of the Asociación de Arte Útil, whose summit was held at mima in July $2016 .^{7}$

Within mima's programming, they have established the 'Office of Useful Art' as well as the Arte Util archive, both of which contribute to informing the development of 'crowd sourced' exhibitions such as Localism (October 2015-Feb 2016). Other recent exhibitions have responded to the closure of the local Redcar Steelworks and forthcoming aspects of the programme include more traditional shows by artists including Winifred Nicholson and Jane and Louise Wilson. Overall, mima strives to stand as a 'useful museum', and in what follows I detail their strategic plan as guided by the principles of Arte Útil, drawing primarily on a series of interviews with Hudson. In particular, I am interested in the histories that Hudson invokes through his notion of the 'museum 3.0' and how these inform his conception of use value.

Fundamentally, mima seeks to break with the history of the modernist art gallery, which Hudson associates with what he calls a Kantian model of autonomy that has affected not only the category of art, but also how art institutions are structured in terms of staffing. ${ }^{8}$ Whereas major galleries like Tate in the UK keep clear divisions between the various arms of the institution (press, development, education, curating), mima seeks to integrate the various departments that make up the museum. To

\footnotetext{
${ }^{6}$ See 'About' section on mima website: http://www.visitmima.com/about/, accessed 18 July 2016

${ }^{7}$ Prior to taking on this role, Hudson had been the Deputy Director of Grizedale Arts in the Lake District, which has long been renowned as a key centre for community art and socially engaged practice in the UK.

${ }^{8}$ Alastair Hudson interview by Axisweb, 'What is Art for? Part One - The Use Value of Art' Available at https://vimeo.com/134189412, accessed 18 July 2016
} 
paraphrase Marx and Engels, mima aims to regulate general production and thus make its staff capable of doing one thing today, and another tomorrow - to write a press release in the morning, run education programmes after lunch, curate an exhibition in the afternoon, meet with private donors in the evening - without ever becoming press officer, curator, development officer, educator. ${ }^{9}$ The idea of melding different departments emerges from the desire to make 'social development' the main goal; meaning that the institution would not have education programmes geared towards contextualising exhibitions, but rather that the entire activity of the museum would revolve around its social programmes.

This guides Hudson's dream of the 'museum 3.0' becoming a 'civic building', comparable to the library, swimming pool, school or town hall. ${ }^{10}$ The main agenda here is to demonstrate how art can apply to everyday life, with Hudson's inspiration drawn from the history of art before modernism, where the relationship between art and day-to-day life was apparently more intimate, via 'ritual', the church and design and thus in his view, more 'useful'. In the present, mima wants to rekindle this intimacy through 'reprogramming' the museum so that art supports what Hudson calls the 'human programme', rather than the reverse, which he views as the dominant model within contemporary art. By 'human programme', Hudson means all those aspects of the art institutions that usually play a supporting role, including the café,

\footnotetext{
${ }^{9}$ In The German Ideology, Marx and Engels famously wrote: 'In communist society, where nobody has one exclusive sphere of activity but each can become accomplished in any branch he wishes, society regulates the general production and thus makes it possible for me to do one thing today and another tomorrow, to hunt in the morning, fish in the afternoon, rear cattle in the evening, criticise after dinner, just as I have a mind, without ever becoming hunter, fisherman, herdsman or critic.' See Karl Marx and Friedrich Engels, The German Ideology: Part One (1845), C. J. Arthur, ed, New York: International Publishers, 2004, p 53

${ }^{10}$ Alastair Hudson interview by Axisweb, 'What is Art for? Part Two - The Museum 3.0', available at https://vimeo.com/134770141, accessed 18 July 2016
} 
the shop, the education programme or the community programme. Hudson then expands on this ambition of reversing the usual dynamic between the 'human programme' and art by describing how mima hopes to transform their relationship to the state, or 'superstructure' as he puts it. Here, the state is understood in terms of its provision of services that contribute to social reproduction such as housing, healthcare, schools and education, and as he explains, mima aims to take on a supporting role within these sectors, with this providing the key to how art can really 'make a difference'. ${ }^{11}$ By playing a more directly supporting role within such sectors, Hudson suggests this might overcome the old paternalistic model of the art institution that affirms the experience of visiting as a process of self-improvement for the poor. ${ }^{12}$ In addition, he suggests that by becoming more 'useful' and 'making a difference', the age-old problem of debating 'what is art' might be over. Through this active dissolution of art's (pretence of) autonomy, it will become less a designation of certain objects, material properties, or processes, and instead could stand as an 'ecology' that simply means undertaking all sorts of activities 'artfully'. As such, Hudson affirmatively cites the more 'everyday' understanding of the 'art of cooking' or the 'art of gardening' as the model to strive towards in reintegrating art with everyday life at mima. ${ }^{13}$

As well as drawing on what Hudson describes as an earlier 'symbiosis between, craft, design and architecture and social activity ${ }^{14}$ he also cites the model of 'usership' common in digital culture as inspiring the museum 3.0. He gives YouTube

\footnotetext{
${ }^{11}$ Ibid

${ }^{12}$ Ibid

${ }^{13}$ Alastair Hudson interview by Axisweb, 'What is Art for? Part Three - Everything is a Project' Available at https://vimeo.com/134770141, accessed 18 July 2016

${ }^{14}$ Alastair Hudson interview by Axisweb, 'What is Art for? Part One - The Use Value of Art' Available at https://vimeo.com/134189412, accessed 18 July 2016
} 
as an example of the relevance of digital cultures to mima, stating that '...the value of YouTube is not created by YouTube - its created by how it's used - (...) the usership creates the value and the meaning of YouTube ${ }^{15}$ Hudson draws a parallel between this and mima's ambitions, suggesting that he wants the 'value of the museum' to be created by its users, from the children who come for workshops, to gallery goers, university researchers, the staff, café visitors and even the drug user in the toilets on the top floor. ${ }^{16}$

The issues that arise within Hudson's desire to use the art institution to support the state, as well as his affirmation of YouTube as a model for mima, both rest on a blindspot with regards to property relations and the inherently exclusionary notion of citizenship. Firstly, in Hudson's suggestion that the 'museum 3.0' might make a difference by supporting the state, or 'superstructure' as he calls it, by mentioning only healthcare, schools and education there has been a parcelling out of the 'good' side of the state, from a traditional social democratic viewpoint. Presumably, mima is not interested in supporting police, prisons or borders guards, all of which exist to guarantee citizenship as it is fundamentally connected to racialisation and property ownership. This parcelling out is then replicated in Hudson's understanding of usevalue, as exemplified in his affirmation of YouTube. Whilst YouTube users may provide the majority of the content, Google owns the company as of 2006, when it was purchased for $\$ 1.6$ billion in stock. ${ }^{17}$ The value apparently produced by its users

\footnotetext{
${ }^{15}$ Alastair Hudson interview by Axisweb, 'What is Art for? Part Two - The Museum 3.0' Available at https://vimeo.com/134770141, accessed 18 July 2016

${ }^{16}$ Ibid

${ }^{17}$ Paul R. La Monica, 'Google to Buy YouTube for \$1.65 Billion', CNN Money, 9 October 2006 , Available at http://money.cnn.com/2006/10/09/technology/googleyoutube_deal/index.htm?cnn=yes, accessed 19 July 2016
} 
and affirmed by Hudson as a model he wishes to emulate is capitalised on by Google, a firm now notorious for tax evasion that therefore fails to contribute to maintaining those aspects of the state that underpin Hudson's very idea of usefulness. ${ }^{18}$

Of course, such shortcomings within Hudson's conception of the 'useful museum' unfortunately demonstrate the systematic nature of that which mima is understandably hoping to disrupt. In emphasising use-value as a quantifiable good, Hudson says that this idea goes back to the 'old idea of the institute, which is the early $19^{\text {th }}$ century incarnation...the DNA of the current art gallery and museum system' where art, science, socialising and provision of basic services would take place in one setting. ${ }^{19}$ In seeking to revivify that model, Hudson suggests that the collection of mima could be used to teach people to make products that they could then sell in the shop, or that mima might provide clothing, food and shelter. These proposals reach their endgame in Hudson's speculation as to whether people should in fact be paid to visit the museum, arguing that 'in a way, that would be an ultimate demonstration of use value. ${ }^{20}$ Notwithstanding the contradiction between viewing the 'institute' as the DNA of the current system and simultaneously viewing it as rooted in a Kantian

\footnotetext{
${ }^{18}$ Earlier in 2016, after reaching a back-tax deal with the Conservative government, critics from the Labour Party and elsewhere claimed the deal was not enough as Google had on average paid only $2.77 \%$ on their profits over the previous decade, compared to the standard $20 \%$ corporation tax on profits. See Daniel Boffey and Jill Treanor, 'Google £130m UK backtax deal lambasted as 'derisory' by expert', The Observer, 23 January 2016, available at https://www.theguardian.com/technology/2016/jan/23/google-uk-back-tax-deal-lambasted-asderisory, accessed 18 July 2016

${ }^{19}$ I am not completely sure what 'institutes' specifically Hudson is referring to but would associate this kind of organisation with Settlement Houses, although the context there is in the United States. For a brief history of settlement houses see Mina Carson, 'Settlement House Movement', in Wilma Mankiller et al, eds, The Reader's Companion to U.S. Women's History, Boston and New York: Houghton Mifflin Company, 1998

${ }^{20}$ Ibid
} 
model, I am wary of the idea that the 'institute' is rooted in a model where members paid in to receive services and 'knew what they got' out of that institution as underpinning the affirmation of 'use-value'. ${ }^{21}$ How much does this model of paying in to receive services that are expected - or in fact being paid to visit - travel beyond the paternalism implicitly criticised by Hudson? Do these ideas not suggest that one form of paternalism (art as a civilising process) has simple been supplanted with another that assumes poor people aren't interested in art unless it fulfils a basic level of social reproduction? Going back to the organisation of the museum, this impoverished quality can also be seen as permeating the plan to amalgamate different departments in the institution. When viewed in relation to consistent cuts to the arts, how does fulfilling multiple roles not signal overwork while wages continue to fall, rather than the destruction of the division of labour?

mima's ambitions, like Arte Útil as a movement, are caught between the utopian and the utilitarian, with art representing the possibility of a utopian transformation, but only once it is rid of its autonomy - all those characteristics which permit it to be somehow 'outside' the everyday. To elaborate further, I want to take up this issue of utopianism and utilitarianism in relation to the history of the avant-garde, and its concern with the category of 'life.'

\section{LIFE AND THE AVANT-GARDE}

The poles of utopianism and utilitarianism fuel the continuation of comparisons between social practice and the avant-garde, which have proliferated since at least the

\footnotetext{
${ }^{21}$ Alastair Hudson interview by Axisweb, 'What is Art for? Part Three - Everything Is a Project', available at https://vimeo.com/134770141, accessed 18 July 2016
} 
early 2000s, despite the apparent novelty of the category of Arte Útil'. In Claire Bishop's often-cited 2006 essay “The Social Turn: Collaboration and Its Discontents", she noted that the "mixed panorama of socially collaborative work arguably forms what avant-garde we have today' with such claims permeating much of the discussion on social practice to one degree or another. ${ }^{22}$ For Stewart Martin, the comparison with the avant-garde underpins his criticisms. As he suggests, the attempt to produce an identity between life and art will not necessarily produce social transformation, as 'life' needs to be understood within the context of capitalist life as a subsumption of life by capital. ${ }^{23}$

Similar arguments to Martin are also put forth by Evan Mauro, who argues that the category of 'life' is inextricably tied to social reproduction in his corrective to Peter Bürger's classic text Theory of the Avant-Garde (1984). Mauro reads this through Michel Foucault's notion of biopolitics, developing a series of historical correspondences. ${ }^{24} \mathrm{He}$ begins with nineteenth century population management and the expansion of the nation state as a biopolitical solution to 'bourgeois liberalism, whose very remoteness from "life" was precisely the complaint of the historical avant-gardes. ${ }^{25}$ Moving beyond the 'historical avant-gardes' as characterised by Bürger, Mauro writes:

\footnotetext{
${ }^{22}$ Claire Bishop, 'The Social Turn: Collaboration and Its Discontents' Artforum, XLIV, No 6, February 2006, p 179. Bishop later developed the relationship between the avant-garde and social practice in her book Artificial Hells: Participatory Art and the Politics of Spectatorship, Verso, London, 2012

${ }^{23}$ Stewart Martin, ‘Artistic Communism - A Sketch', Third Text, vol. 23, issue 4, July 2009, pp 481-94

${ }^{24}$ Evan Mauro, 'The Death and Life of the Avant-Garde: Or, Modernism and Biopolitics', Mediations: Journal of the Marxist Literary Group, Vol 26, Nos 1-2, Fall 2012 - Spring 2013, p 135

${ }^{25}$ Ibid
} 
After the midcentury realization of biopolitical state forms, but before the subsequent institutional critiques of the Keynesian regulation of social life, and the ways these critiques were repurposed by a resurgent neoliberalism to scale back the institutional security of "life" under the midcentury nation-state in favor of greater flexibility, precarity, and self-management - these, and not only the logic of commodification, make up the "politics" against which the avant-garde needs to be defined. ${ }^{26}$

In stressing that the 'life' side of the avant-garde dialectic must be viewed as correspondent with social reproduction, Mauro offers a corrective to Bürger's argument, which views the decline of the 'historical' avant-garde as primarily related to the gradual institutionalisation and commodification of its artworks. ${ }^{27}$ If we stay with Mauro's focus on 'life', it becomes clear that the majority of artworks contained under the banner of Arte Útil are situated as 'useful' for their provision of tasks associated with aspects of social reproduction that are necessary to life. As Hudson stresses, healthcare, housing and education form areas into which mima might intervene. Childcare is also mentioned, as is the 'art of cooking'; all activities that fall under the banner of social reproduction as a category that denotes the reproduction of labour power, generationally and through maintenance. This aspect of Arte Útil forms its most significant link to the avant-garde, whilst the emphasis on usefulness marks its comparative weakness against the desire for a sublation of the categories of art and life. In order to qualify this further and address Arte Útil's biopolitical implications, let us turn to an artwork that directly sought to intervene into the crisis of social reproduction.

WochenKlausur are an Austrian collective that were featured prominently in the 'Museum of Arte Útil' at the Van AbbeMuseum. Here, staying in a British context,

\footnotetext{
${ }^{26}$ Mauro, op cit, pp 135-6

${ }^{27}$ Peter Bürger, The Theory of the Avant-Garde, Michael Shaw, trans, Manchester University Press, Manchester, 1984
} 
their project to create a Women-led Workers Cooperative in Drumchapel, Glasgow is notable. As WochenKlasur's website explains, entrepreneurs have left Drumchapel since the late $1970 \mathrm{~s}$ and the area is one with high unemployment that is now entrenched over three generations. ${ }^{28}$ This led WochenKlasur to encourage a group of unemployed women to form a cooperative who subsequently decided to address the health problems that affected many in the area as a result of poor diet. WochenKlasur and the group they facilitated opened a shop selling 'meal bags' which contained fresh fruit and vegetables and simple recipes to encourage healthy cooking. The project also provided employability training and skills development for these women in business planning, marketing and accounting. In this project, there are two stages of dealing with faltering social reproduction. The women engaged by WochenKlasur were not working and facing barriers, and then the project they produced was centred on encouraging "better" levels of social reproduction within a relatively impoverished neighbourhood. Overall, WochenKlasur worked with a population viewed as a 'burden' by the British state - the unemployed - at a time when government schemes including Mandatory Work Activity and the Community Action Programme required claimants to take up work placements in order to continue receiving benefits. The project thus tended to cohere with, rather than confront, the paternalism of the state and capitalism as a mode of production within which - as Michael Denning writes 'the only thing worse than being exploited is not being exploited. ${ }^{, 29}$

\footnotetext{
28 See the description of the project on WochenKlausur's website: http://www.wochenklausur.at/projekt.php?lang=en\&id=41, accessed 18 July 2016

${ }^{29}$ Michael Denning, 'Wageless Life' New Left Review, 66, November-December 2010, p 79
} 
Within Arte Útil, Bruguera writes that 'failure is not a possibility. If the project fails, it is not Arte Útil. ${ }^{30}$ Through this, Bruguera implies that the stakes are higher and the possibility of experimentation is lower, despite the desires for Arte Útil and institutions like mima to prioritise aesthetics as a system of transformation. Within Arte Útil institutions and projects, artists are explicitly positioned as providing services that enable the reproduction of individuals. The reason Arte Útil 'cannot fail' is because the state and capital have already decided that the people Arte Útil seek to engage are irrelevant. The women of Drumchapel that WochenKlasur worked with were essentially being encouraged to make themselves less disposable in the eyes of the state and capital - along lines that conform to extremely violent and normative notions of usefulness.

What then are the politics of affirming the affective, reproductive and 'useful' dimensions of social practice today as its aesthetic and political link to the avantgarde? If these aspects have tended to cohere with - rather than confront - state and capital, how does this connect with Bruguera's statement that 'when the work is properly done, the artist also expands their own spectrum as a citizen and as a person' 31 , as well as Hudson's affirmation of mima as a 'civic institution'?

\section{USEFUL CITIZENS}

30 Tania Bruguera, Reflexions on Useful Art, November 2012, available at http://www.taniabruguera.com/cms/592-0-Reflexions+on+Arte+til+Useful+Art.htm, accessed 11 July 2016

${ }^{31}$ Alex Kershaw interview with Tania Bruguera, 'Immigrant Movement International: Five Years and Counting', Field: A Journal of Socially Engaged Art Criticism, 1, Spring 2015, p 20, vailable at http://field-journal.com/issue-1/bruguera, accessed 18 July 2016 
Citizenship within bourgeois society is founded in property ownership and work, and those apparently 'not working' in the eyes of the state have long been compelled to become productive through a variety of means, including the Victorian workhouse, contemporary workfare initiatives and the use of prison labour. Through such measures, the capitalist state has produced differential levels of citizenship, dependent on one's access, as Marx describes, to the double freedom that comes with wage labour (free to sell one's labour, and free of any other commodity to sell). ${ }^{32}$ Women have historically lacked full citizenship alongside migrants, prisoners, people of colour and the totally dispossessed. In the United States, we might mention how police violence and the prison system continues the structural anti-blackness founded by slavery as a means to void full or even partial citizenship; for Frank Wilderson 'black citizenship and black civic obligation are oxymorons.' ${ }^{33}$ Or, in the UK, we might refer to the removal of jus soli (birth right citizenship) from the 1981 Nationality Act, rendering many people who had grown up in the country with migrant parents suddenly precarious. The Act also radically racialised the possibilities of obtaining citizenship for those born in former British colonies by asking residents of the Commonwealth to prove they had British ancestry, meaning that those who would qualify were far likelier to be white. ${ }^{34}$

\footnotetext{
${ }^{32}$ Karl Marx, Capital: A Critique of Political Economy Volume 1, Ben Fowkes, trans, Penguin Books, London, 1990, pp 272-3

${ }^{33}$ Frank B. Wilderson III, 'The Prison Slave as Hegemony's (Silent) Scandal', in Joy James, ed, Warfare in the American Homeland: Policing and Prison in a Penal Democracy, Duke University Press, Durham NC and London, 2007, p 23

${ }^{34}$ Notably, one precedent to the 1981 Nationality Act's racialised relinquishing of jus soli can be observed in the British government's pre-emancipation exclusion of slaves born in their American colonies from birthright citizenship. For a discussion of jus soli and the 1981 Nationality Act, see Ian Baucom, Out of Place: Englishness, Empire, and the Locations of Identity, Princeton: Princeton University Press, 1999. For a more recent discussion of
} 
These limits of citizenship are also mapped onto dispossession more broadly; as Carole Pateman stresses 'poverty-stricken individuals are not, and, unless the outcome of participation in the market is offset in some way, cannot be, full citizens. ${ }^{35}$ As such, the moral basis of the welfare state partly lies in its ability to 'offset' the market and provide resources for incorporation into citizenship for those who are not working, or whose work is unrecognised as work for reasons of racism, impoverishment, criminalisation and patriarchy. This 'offsetting' is essential because mass unemployment is a permanent feature of capitalist economies, and the state must therefore form a means to, as David Harvey writes, produce a 'structured coherence' in tandem with wage labour. ${ }^{36}$ This idea of 'structured coherence', and the process of incorporation and expulsion from citizenship via the state, links to social reproduction and usefulness, and reveals some of the problems in affirming these categories as emancipatory or radical, especially where they are simply offsetting or minimising damage.

Moreover, the dynamic between citizenship and work is founded upon the continued differentiation between forms of 'real work' deserving of citizenship and other activity not recognised as legitimately incorporated into wage labour, such as the work done by undocumented migrants and prisoners, traditionally female gendered activity and slave labour. This dichotomy between work and non-work has a moral (and thus an ethical) function and feminists, abolitionists, activists and artists have long sought to trouble and attack this dynamic. Aspects of current social practice citizenship and race in Britain, see Imogen Tyler, Revolting Subjects: Social Abjection and Resistance in Neoliberal Britain, Zed Books, London, 2013

${ }^{35}$ Carole Pateman, 'The Patriarchal Welfare State', in Amy Gutman, Democracy and the Welfare State, Princeton University Press, Princeton, 1988, p 235

${ }^{36}$ David Harvey, The Urban Experience, Baltimore: The John Hopkins University Press, 1989, p 145 
continue in this vein, with mima's calls for people to be paid to visit the museum undoubtedly stemming for a well-intended desire to challenge the way that different forms of activity are valued as work and non-work. However, like the recent growth in calls for a Universal Basic Income (UBI), this fails to recognise the foundational issue of private property as cornerstone of capitalism, as well as the ever-present, frequently violent regulation of who counts as citizen within various state formations. These two central limits also permeate the discourse and politics of accelerationism, which has taken up the call for UBI.

As two key proponents of accelerationism, Nick Srnicek and Alex Williams note, three factors are needed to make UBI meaningful. ${ }^{37}$ It must provide enough money to live on, be given out unconditionally, and it must supplement rather than replace the welfare state. The first and third elements of this argument relate to the requirements UBI must fulfil if it is not to support increased marketisation. ${ }^{38}$ The second point, around unconditional access, draws us further into the issues arising from Arte Útil's emphasis on citizenship. I see the primary risk and limit with UBI in how it risks coherence with rising anti-immigrant rhetoric and policies across popular discourse and the media, governmental policy and legislation. Whilst Srnicek and Williams' caveat that UBI would have to be universally accessible by immigrants and prisoners thankfully seeks to counter this prospect, I find their faith in the possibility of this in the present moment doubtful and indicative of accelerationism and Arte Útil's shared

\footnotetext{
${ }^{37}$ Srnicek and Williams authored the "\#Accelerate Manifesto for an Accelerationist Politics" (2013) but have since stated that they avoid the term accelerationism because of the "miasma of competing understandings that has arisen around the concept'. However, they also explain that they have not abandoned its principles as they understand them. Nick Srnicek and Alex Williams, Inventing the Future: Postcapitalism and a World without Work, Verso, London, 2015. See chapter 1 , fn 54

${ }^{38}$ See the chapter 'Post-work imaginaries' in Srnicek and Williams, op cit
} 
failure to adequately consider and respond to the ways that their central emphasis on citizenship and technology have been drawn into the very heart of right wing discourse and politics. ${ }^{39}$

We can see that calls for UBI from the accelerationist camp align with Hudson's ideas, particularly those that suggest payment for visiting the museum, as well as his affirmation of 'usership'. The limits of these arguments lie in their quality as 'forcesof-production' solutions that fail to address the relations of production. Along the same conceptual lines, 'use value' cannot be affirmed as a weapon against value in the present because it is only made coherent through its relation to exchange value. Just as how I believe UBI - in our present moment - would unfortunately be taken up in tandem with a further enshrining of discriminatory forms of citizenship via providing an income that was guaranteed for some and utterly inaccessible for others, we must critically consider how and why certain patterns of behaviour and activity are registered as useful in the present. Use is not a neutral, or straightforwardly 'good' category but one that is shaped by history, in the same way that the determination of the value of labour power, unlike other commodities, 'contains a historical and moral element. ${ }^{, 40}$ The 'historical and moral element' that partly determines the value of labour power precisely signals the whole arena of social reproduction, and that which is affirmed because of its usefulness by Arte Útil.

\footnotetext{
${ }^{39}$ This is especially pressing now with regards to accelerationism's shared intellectual heritage with the so-called 'alt-right' and 'neo-reactionary' movement, with Nick Land standing as the central figure. See Benjamin Noys, 'Futures of Accelerationism', talk given at FASTER/SLOWER/FUTURE: The Road to Post-Capitalism, Kaaitheater, Brussels, Belgium 22-23 October, 2016, available at https://www.academia.edu/29295882/Futures_of_Accelerationism, accessed 28 November 2016

${ }^{40}$ Marx 1990, op cit, p 275
} 
For Srnicek and Williams, social reproduction could be transformed and made more efficient through a 'forces of production' solution. As they write, 'Assistive technologies and affective computing are...making inroads in automating some of the highly personal and embarrassing care work that might be better suited to impersonal robots. ${ }^{41}$ Now this automation might work happily in some situations, but it is also very easy to imagine the automation of care as related to diminished numbers of nurses and careworkers within the context of an expanded aging population. As Nina Power writes, the accelerationist drive towards automation is overwhelmingly marked by a 'desire for a lack of dependency ${ }^{42}$ with the affirmation of robotic care work encapsulating this. The 'useful' dimensions of such a robot are clear, but the quality of the relations through which that use is manifested are never guaranteed, in the same way a knife may be used to cut bread or stab someone, to put it crudely. The material object is useful in both situations but there is no positive content to 'use value' as such. As Marx writes, use values become a reality 'only by use or consumption' and the mode, or relations, of use or consumption are variable. ${ }^{43}$

\section{USEFULNESS, SOCIAL REPRODUCTION AND SOCIAL PRACTICE}

In aspects of social practice, we can see the fetishisation of usefulness as emerging from a desire - that like elements of accelerationism - seeks to 'mirror' and thus exceed the workings of state and capital from a supposedly progressive perspective. A

\footnotetext{
${ }^{41}$ Srnicek and Williams, op cit, p 114

${ }^{42}$ Nina Power, 'Decapitalism, left scarcity and the state', Fillip, 20, Fall 2015, available online at http://fillip.ca/content/decapitalism-left-scarcity-and-the-state, accessed 25 November, 2016

${ }^{43}$ Marx 1990, op cit, p 126
} 
recent two-part feature for $e$-flux entitled 'The Insurgents' by Nato Thompson, chief curator of Creative Time, the foremost commissioning organisation within social practice, encapsulates this approach. ${ }^{44}$ Thompson describes the 'cultural turn' of the US military during the last Iraq war and how they sought to capture 'hearts and minds' through counter-insurgency efforts that drew on anthropological research, as well as writing by Antonio Gramsci and the radical pedagogue, Paolo Freire. As Thompson writes 'It should come as no surprise that the military, in its effort to gain hearts and minds, found itself in dialogue with the methodologies of its ideological adversaries. A tool is a tool. ${ }^{45}$ Following the military's appropriation of historically leftist thought, Thompson elaborates a series of connections between feminist artist and social practice forerunner Suzanne Lacy, community organiser Saul Alinsky, the Black Panthers and the general commanding the US Army in Iraq from 2007-2008, David Petraeusas, as all 'employing community organizing techniques'. ${ }^{46}$ Thompson's comparison between the arts and the military rests on the belief that

while the ends pursued by these two spheres are radically different, aspects of their means are startlingly similar. Comparing examples according to means and not ends offers a new method for understanding formal approaches to the construction of a public. As the manipulation of culture becomes a major priority across a range of disciplines, it might prove instructive to overlook disciplinary boundaries and simply compare methodologies. ${ }^{47}$

\footnotetext{
${ }^{44}$ See Nato Thompson, 'The Insurgents, Part I: Community-Based Practice as Military Methodology', e-flux, 47, September 2013, available at http://www.e-flux.com/journal/theinsurgents-part-i-community-based-practice-as-military-methodology/, accessed 23 June 2016, and Nato Thompson, 'The Insurgents, Part II: Fighting the Left by Being the Left', eflux, 49, November 2013, available at http://www.e-flux.com/journal/the-insurgents-part-iifighting-the-left-by-being-the-left/, accessed 23 June 2016

${ }^{45}$ Thompson, 'The Insurgents, Part I', op cit

${ }^{46}$ Thompson, 'The Insurgents, Part II', op cit

${ }^{47}$ Ibid
} 
Yet, in suggesting that the cultural and progressive spheres should learn 'new ideas and new methodologies concerning tactics for "getting to know people" 48 from the military, Thompson entirely delinks strategy from tactics, or forces from relations in a similar manner to Hudson's affirmation that art should support the superstructure. ${ }^{49}$ I view this lack of care as coterminous with the ultimately uncritical attitude towards the category of 'life', with 'life' often posed as boundlessly creative and productive rather than as fundamentally linked to social reproduction. For example, the accelerationists argue that the left must 'reconnect' to its Enlightenment roots - a 'rationalist and universal vision of collective human self-construction' that might 'enable, rather than suppress, a generalised human flourishing. ${ }^{50}$ As Ben Noys stresses, such statements are intended to be 'politically motivational', seeking to break the sense of inertia in the face of global capitalism; we can say much the same of Arte Útil and social practice in contrast with the corrupt, exploitative machinations of the mainstream art world. ${ }^{51}$ Yet,

\footnotetext{
${ }^{48}$ Thompson, 'The Insurgents, Part I', op cit

${ }^{49}$ Ray Brassier has commented on the problem of delinking strategy and tactics. In reckoning with his intellectual debt to Land after his move from a Deleuzian, accelerationist position to a far right, 'neo-reactionary' political and a philosophical position, Brassier states that '...once you dissociate tactics and strategy - the famous distinction between tactics and strategy where strategy is teleological, transcendent, and representational and tactics is immanent and machinic - if you have no strategy, someone with a strategy will soon commandeer your tactics. Someone who knows what they want to realize will start using you.' Ray Brassier, 'Accelerationism', talk at the Accelerationism conference, Goldsmiths University, 14 September 2010, available at https://moskvax.wordpress.com/2010/09/30/accelerationism-raybrassier/2 accessed 1 December 2016

${ }^{50}$ Armen Avanessian, Nick Srnicek and Alex Williams, “\#Accelerationism: Remembering the Future', originally published in Tag Allgemeiner Zeitung, 4 February 2014. English translation available at https://syntheticedifice.files.wordpress.com/2014/02/srnicek-williamsand-avanessian-2014-remembering-the-future1.pdf, accessed 27 July 2016

${ }^{51}$ Ben Noys, “Grey in Grey': Crisis, Critique, Change'. Journal of Critical Globalisation Studies, 4, 2011, p 52
} 
whether considering Thompson's 'practical' desire to learn from the military, Hudson's affirmation of 'usership' the 'civic' and the 'superstructure', or the accelerationist's affirmation of enlightenment rationality, all these arguments seek to discover and harness an excessive, vital force that cannot be fully captured by capital, without considering how those very categories may be taken up in ways that are cogent with existing and emerging forms of violence and exploitation. In this final section, I want to more closely consider how similar claims - and difficulties - emerge in claims that have been made for the status of women's political agency as tied to social reproduction and how this further opens itself up onto the limits of Arte Útil.

Silvia Federici is one of the most significant voices here through her articulation of an idea of the 'reproductive commons'. As Federici writes, the notion of the commons became important within the alter-globalisation movement, and the turn away from statist models of socialism, forming a response to the 'new enclosures' of 'neoliberal attempts to subordinate every form of life and knowledge to the logic of the market' ${ }^{52}$ For Federici, urban gardens form a significant element in the processes of commoning since the 1980s in the United States. She associates the development and growth of these with migrants from Africa, the Caribbean and the South of the United States and their importance lies not only in providing food security for neighbourhood consumption, rather for commercial purposes, but also in strengthening communities and diversifying cultural practices. ${ }^{53}$ Notably, the 'urban garden' has become a frequent feature of Arte U'til, with the 'Common Ground' project associated with the

\footnotetext{
${ }^{52}$ Silvia Federici, 'Feminism and the Politics of the Commons in an Era of Primitive Accumulation' in Revolution at Point Zero, PM Press/Common Notions/Autonomedia, New York, pp 138-9

${ }^{53}$ Federici, op cit, pp 141-2
} 
'Museum of Arte Útil' exhibition at the Van Abbemuseum providing one such example. $^{54}$

Yet, Federici also stresses that such attempts at commoning have tended to remain stuck at the grassroots. ${ }^{55}$ This is precisely the kind of limit that has prompted criticism from the accelerationist camp, with Avanessian, Srnicek and Williams denigrating 'the fantasy of local, small-scaled solutions to our many crises', characterising them as 'organic', 'localist' and 'folk politics'. 56 The problem with this view is that it does not recognise the internationalism of the struggles somebody like Federici is championing, or their gendered dimensions. As she writes, 'women are the main force standing in the way of a complete commercialisation of nature', offering examples of resistance primarily from the global south. ${ }^{57}$ Despite the force of Federici's argument as a necessary corrective to the accelerationist fantasy of full automation, her valorisation of reproductive labour as incipiently revolutionary has become a sticking point for other feminists. Stressing that 'assigning women the task of communing/collectivizing reproduction is not to concede to a naturalistic conception of "femininity", Federici

\footnotetext{
54 'Common Ground' emphasises working with food 'as a basic need', and describe their aim in building a cooperative network that brings people closer together. However, all too often, these art world initiatives do not investigate the gendered dimension of 'the commons' that Federici's analysis thankfully made so prominent. Instead, projects such as Common Ground - and I am perhaps being unfair by taking this to stand for a whole tendency- frequently tend to link up with architecture and design firms in order to amp up the 'useful', 'practical' dimension. Too often, these partnerships shift the orientation of the work away from a utopian imaginary and towards the cultivation of shared resources among white, bourgeois urbandwelling individuals with a hankering for the rural. See the Common Ground website http://museumarteutil.net/arte-util-and-common-ground-project/, accessed 18 July 2016.

${ }^{55}$ Federici, op cit, p 142

${ }^{56}$ Avanessian, Srnicek and Williams, op cit

${ }^{57}$ Federici, op cit, $\mathrm{p} 143$
} 
nevertheless acknowledges that 'many feminists would view this as a "fate worse than death.", 58

In an article entitled 'The Logic of Gender', published in Endnotes 3, the authors concede that Federici is right - that they do consider her proposition to be "worse than death' - going on to state that 'even if we might, in the crisis, have no choice but to self-organise these reproductive activities — and even though, most likely, abject reproduction will in the end mainly be foisted upon women — we must fight against this process which reinforces gender. ${ }^{, 59}$ The category of the 'abject' in this article extends Julia Kristeva's concept beyond the individual to describe activities that were once waged, but are in the process of returning to the unwaged sphere 'because they've become too costly for the state or capital. ${ }^{60}$ Marina Vishmidt and Zöe Sutherland have also criticised Federici for potentially idealising 'subsistence scenarios', thus producing a 'conflation of necessity and desirability, particularity and universality, gendered drudgery in the austerity present and utopian horizons. ${ }^{61}$ These criticisms of subsistence models reverberate with the shortcomings I have outlined in Arte Útil as cohering too closely with the logic of austerity through the impoverished quality of how 'usefulness' is conceptualised in relation to a (hopefully) more utopian horizon. Moreover, as mima and Arte Útil more broadly volunteers itself as keen to take on aspects of social reproduction previously provided through the state or

\footnotetext{
${ }^{58}$ Federici, op cit, p 147

${ }^{59}$ Endnotes, 'The Logic of Gender', Endnotes, 3, September 2013, p 89, available at https://endnotes.org.uk/en/endnotes-the-logic-of-gender, accessed 20 July 2016

${ }^{60} \mathrm{Ibid}$

${ }^{61}$ Marina Vishmidt and Zöe Sutherland, 'Social Reproduction Feminism: A Critique', talk at the Social and Political Thought Conference, University of Sussex, 20 June 2015
} 
employment, does this then produce a very different notion of 'abject art' to the representational strategies we usually associate with this term? ${ }^{62}$

Lise Vogel's stress on the necessity of thinking through the lens of overall social reproduction offers a helpful corrective to the valorisation of reproduction by Federici, and the uncritical affirmation of reproductive activities as useful within Arte Útil. Vogel describes the social reproduction of labour power as a system that knits together the active labor force, the industrial reserve army and that portion of the relative surplus population not incorporated in the industrial reserve army. Vogel stresses that within the history of capitalism, this last category - the surplus population - has sometimes included very few persons, aside from very young children. ${ }^{63}$ This is certainly not the case in the present due to the collapse of Fordism and a family wage, alongside the economic restructuring of welfare and the ongoing accumulation of capital through means that are radically severed from the reproduction of the proletariat. Moreover, in thinking about Federici's affirmation of the reproductive commons, it is important to stress Vogel's emphasis that the maintenance and replacement of the totality of laborers has always been achieved in

\footnotetext{
${ }^{62}$ The popularity of Julia Kristeva's theory of abjection for a reading of artworks reached an apex in the mid-1990s, spurred on by the exhibition Abject Art: Repulsion and Desire in American Art, Whitney Museum of Art, 1993. See the catalogue Craig Houser, Leslie C. Jones et al, eds, Abject Art: Repulsion and Desire in American Art, New York: Whitney Museum of Art, 1993. Hal Foster also gives an account of Cindy Sherman and Kiki Smith's work in terms of the abject as specifically feminine; see Hal Foster, 'Obscene, Abject, Traumatic', October, Vol 78, Autumn, 1996, pp 106-124. More recently, Hannah Black has discussed the revival of representational strategies associated with abjection in contemporary art, adding a much-needed discussion of race to the picture. See Hannah Black, 'This Is Crap?' Frieze d/e, 23, Spring 2016, available at https://frieze.com/article/crap, accessed 1 December 2016

${ }^{63}$ Lise Vogel, Marxism and the Oppression of Women: Toward a Unitary Theory, Rutgers University Press, New Brunswick, 1983, p 158
} 
other ways than generational replacement and the reproduction of the male worker by his female spouse, through labour camps, workers dormitories and prisons, all of which are heavily intertwined with violent processes of racialisation managed by the state that were previously discussed as foundational to the exclusions of citizenship. ${ }^{64}$ Taking this view allows us to avoid an affirmative, moralising view of social reproduction as such, in the same way I have already detailed around use value.

Moreover, by paying attention to the question of race and migration as introducing a 'combined and uneven' aspect to social reproduction, I believe we can avoid making a 'moral' argument for a return to what Heide Gerstenberger describes as the 'domesticated capitalism' of Fordism ${ }^{65}$, accelerationism's emphasis on rational, 'forces of production' solutions and Federici's support of what we might call subsistence models, all of which have penetrated the ideological ground of Arte Útil in varying degrees and dimensions. When contemporary artists attempt to re-animate individuals and communities who have otherwise been condemned as disposable left to not-reproduce themselves - in the present this too often involves taking on aspects of social reproduction to 'repurpose' those populations and make them 'useful' along lines that draw tacit support by the state and capital.

I want to end by mentioning a recent social practice project I see as successfully working against this tendency. Simone Leigh's Free People's Medical Clinic (FPMC) (2014) was organised through the 'Funk, God, Jazz and Medicine: Black Radical Brooklyn' project, a collaboration between Creative Time and the Weeksville

\footnotetext{
${ }^{64}$ Vogel, op cit, p 139

${ }^{65}$ Heide Gerstenberger, 'The Political Economy of Capitalist Labor', Viewpoint Magazine, 4, special issue The State, 2 September 2014, available at https://viewpointmag.com/2014/09/02/the-political-economy-of-capitalist-labor/, accessed 20 July 2016
} 
Heritage Centre (Weeksville, Brooklyn). ${ }^{66}$ The Clinic drew on histories including the Black Panther Party's free clinics and the United Order of Tents, a secret society of black nurses founded in 1867 by former slaves Annette M. Lane and Harriett R. Taylor. The FPMC provided well-woman care, doula services, massage, blood pressure screening, HIV testing, counselling, lectures on herbalism as well as dance workshops based on legendary African American dancer Katherine Dunham's technique, yoga and pilates. The project was situated in the former home of Dr. Josephine English, the first black woman to have a gynaecological practice in the state of New York. Leigh's project sought to draw on these legacies as a means to contest racialised healthcare in the United States, a history marked by notorious cases such as the infection of 600 black men with syphilis in the Tuskegee medical study as well as to address more recent incidents such as the death of 49 year old African American woman Esmin Elizabeth Green. Green died in June 2008 after waiting 24 hours in the psychiatric emergency room of Kings County Hospital in Brooklyn. ${ }^{67}$

The case of Green's death directly influenced Leigh's conception of the waiting room in the Free People's Medical Clinic as a 'space of impossible memorialization... and a space where aesthetic ideas can get worked out. I am compelled by this idea that the artistic form is as important as the information the form delivers. ${ }^{68}$ As Leigh states, in producing this work, she was clear that she was 'not a public health expert' but an artist who believes that 'the number one killer of

\footnotetext{
${ }^{66}$ For details of the project see Rizvana Bradley, 'Going Underground: An Interview with Simone Leigh', Art in America, 20 August 2015, available at $\mathrm{http} / / / \mathrm{www}$.artinamericamagazine.com/news-features/interviews/going-underground-aninterview-with-simone-leigh/, accessed 27 November 2016

${ }^{67}$ Ibid

${ }^{68}$ Ibid
} 
black women in the U.S. is obedience. ${ }^{69}$ The Free People's Medical Clinic sought to revivify past struggles as a rallying call against this obedience, drawing on Afrocentric imaginaries, 'bodily knowledge' as well as contemporary medical emergencies such as HIV to produce both a quasi-autonomous site from which to gain energy for present struggles as well as a glimpse into how healthcare might be more widely re-organised in a transformed future. In its offensive against 'obedience' and attention to form as well as 'information', the Free People's Medical Clinic could not be further away from the 'usefulness' of Wochenklausur, the other project mentioned in this article that centred on health. Whilst Wochenklausur's project tacitly encouraged obedience and compliance with the restructuring of welfare - its usefulness lying in its symbiosis with the world around it - the Free People's Medical Clinic contested and asked difficult questions of the surrounding medical infrastructure. As such, the FPMC actively contradicts and refuses the logics of the world that produced the necessity for art to step into the arena of social reproduction, and in doing so is marked by an attention to history as well as the kinds of expressive, material and emotional solidarity I called for at the outset of this article.

${ }^{69}$ Ibid 